\title{
Human Pegivirus (GB Virus Type C) and Its Relationship with HIV
}

\author{
Insan Pegivirus (GB Virüs Tip C) ve HIV ile Olan llișkisi
}

\author{
Ferhat Gürkan ASLAN, Mustafa ALTINDIŞ \\ Sakarya University Faculty of Medicine, Department of Medical Microbiology and Virology, Sakarya, Turkey
}

Keywords: Human pegivirus, GB virus C, Hepatitis G virus, HIV

Anahtar Kelimeler: Insan pegivirus, GB virus C, Hepatit G virus, HIV

Aslan FG, Altındis M. Human Pegivirus (GB Virus Type C) and Its Relationship with HIV. Viral Hepat J. 2016;22:113-114.

\section{Dear Editor;}

Human pegivirus ( $\mathrm{HPgV}$ ) is a RNA virus which is classified in Flaviviridae family. The virus is named as hepatitis $\mathrm{G}$ virus (HGV) or GB virus type C (GBV-C) (1).

$\mathrm{HPgV}$ was initially considered as hepatotropic depending on its definition in humans with non- $A$, non- $B$, and non-C hepatitis. Then, no association was found between acute or chronic hepatitis and HPgV. Therefore, virus (HGV or GBV-D) together with primate and bat viruses (GBV-A, GBV-Cczp, GBV-D) were included in a new genus (Pegivirus). It was again named as HPgV. HPgV infection can occur via exposure to infected blood, sexual contact, and motherto-child transmission (1).

$\mathrm{HPgV}$ can cause infections either alone or in combination with other factors such as hepatitis $\mathrm{C}$ virus $(\mathrm{HCV})$ and HIV. The effects of this virus on chronic infections with hepatitis $\mathrm{B}$ virus or $\mathrm{HCV}$ have not yet been clarified (2). Furthermore, it was shown that the prevalence of HPgV increased in individuals infected with $\mathrm{HCV}$ and the HCV RNA levels were permanently high in livers of individuals infected by the combination of HCV/HPgV (1). It was specified that $\mathrm{HPgV}$ infection can have effects on chronic infection development or drug resistance (2). Viral hepatitis is commonly observed in chronic dialysis patients. The risk of HPgV infection increases in hemodialysis patients. However, this risk is lower in continuous ambulatory peritoneal dialysis patients (3).

Besides HPgV is associated with beneficial effects in HIV infection. Various studies and a meta-analysis found that survival in HIV-infected individuals was longer in patients with HPgV viremia compared to those without viremia (4). It was concluded that GBV-C viremia was associated with lower mortality in HIV-infected patients. As a result of $T$ cell activation which happens due to HIV infection, immune functions deteriorate and AIDS progresses after the loss of CD4 (+) T cells. In contrast, compared to chronic HIV-infected patients without HPgV infection, HPgV infection in patients with acute HIV infection is associated with significant decrease in the expression of $T$ cell activation markers. This is independent from treatment (1). In comparison to inactive cells, HIV replication decreases in active peripheral blood mononuclear cells and this finding supports the relationship between HPgV and T cells proliferation (5).

Consequently, when its clinical outcomes and co-infections are considered, even though HPgV is a non-cytopathic factor, there should be further studies investigating the relationship between HIV-1 subtypes and HPgV infection as well as the possible molecular and cellular mechanisms behinds its effects.

\section{Ethics}

Peer-review: External and Internal peer-reviewed.

\section{Authorship Contributions}

Concept: Mustafa Altındiș, Ferhat Gürkan Aslan, Design: Mustafa Altındiş, Ferhat Gürkan Aslan, Data Collection or Processing: Ferhat Gürkan Aslan, Mustafa Altındiş, Analysis or Interpretation: Mustafa Altındiş, Ferhat Gürkan Aslan, Literature Search: Mustafa Altındiş, Ferhat Gürkan Aslan, Writing: Ferhat Gürkan Aslan, Mustafa Altındiş.

Address for Correspondence: Ferhat Gürkan Aslan MD, Sakarya University Faculty of Medicine, Department of Medical Microbiology and Virology, Sakarya, Turkey Phone: +90 5432912980 E-mail: ferhatgurkan33@hotmail.com Received: 18.09.2016 Accepted: 24.11.2016

${ }^{\circ}$ Copyright 2016 by Viral Hepatitis Society / Viral Hepatitis Journal published by Galenos Yayınevi. 
Conflict of Interest: No conflict of interest was declared by the authors.

Financial Disclosure: The authors declared that this study received no financial support.

\section{References}

1. Chivero ET, Stapleton JT. Tropism of human pegivirus (formerly known as $\mathrm{GB}$ virus $\mathrm{C} /$ hepatitis $\mathrm{G}$ virus) and host immunomodulation: insights into a highly successful viral infection. J Gen Virol. 2015;96:1521-1532

2. Alhetheel A, El-Hazmi MM. Hepatitis G virus in Saudi blood donors and chronic hepatitis B and C patients. J Infect Dev Ctries. 2014;8:110-115
3. Yavuz M, Ersoy A, Güllülü $M$ et al. Risk factors for Hepatitis B and Hepatitis $C$ prevalence in Continuous Ambulatory Peritoneal Dialysis (CAPD) patients: 6 years data of a CAPD center. Bursa Devlet Hastanesi Bülteni. 2000;16:43-46.

4. Williams CF, Klinzman D, Yamashita TE, Xiang J, Polgreen PM, Rinaldo C, Liu C, Phair J, Margolick JB, Zdunek D, Hess G, Stapleton JT. Persistent GB virus C infection and survival in HIVinfected men. N Engl J Med. 2004;350:981-990.

5. Rydze RT, Bhattarai N, Stapleton JT. GB virus C infection is associated with a reduced rate of reactivation of latent HIV and protection against activation-induced T-cell death. Antivir Ther. 2012;17:1271-1279 